\title{
Podaxis pistillaris (L.) Fr. and Leucocoprinus birnbaumii (Corda) Singer; New addition to Macrofungi of Egypt
}

\author{
A.A. El-Fallal, A.K.A. El-Sayed ${ }^{\#}$ and H.M. El-Gharbawy \\ Botany and Microbiology Department, Faculty of Science, Damietta University, \\ Damietta El-Gededa 34517, Egypt.
}

\begin{abstract}
$\mathbf{A}^{\mathrm{c}}$ GARICACEAE is a widely distributed monophyletic family of saprotrophic fungi, includes a large number of genera and species of nutritional and medicinal mushrooms. However, few literatures have been published on wild members of Agaricaceae in Egypt. Two basidiomycetes from family Agaricacea were recorded for the first time in Egypt during macrofungal surveys. The first; Podaxis pistillaris fallal (Lin.Ex.Pers) Fr.;a desert puffball was growing solitary on sandy soils in Zaranik protected area at North Sinai during spring season. The second; Leucocoprinus birnbaumii EGDA (Corda) Singer; a gilled mushroom was growing in small group on a dead stump of lemon tree in El-Sinania orchards at Damietta during autumn season. The collected agaricoid were identified based on macro and microscopic laboratory features. Phylogenetic analysis of ITS sequences was used to confirm the fungal identification and verify their taxonomic position with other related genera. A detailed description of both species and the ecological features of their habitat are provided.
\end{abstract}

Keywords : Egyptian macroflora, Mushroom, Agaricacea, ITS phylogeny, New records.

\section{Introduction}

Family Agaricaceae is a widely distributed monophyletic group of saprotrophic fungi. It contains 85 genera and 1340 species of edible, medicinal or poisonous mushrooms (Kirk, 2008). These fungi exhibit a huge diversity in morphology as spore colour and structure of the pileus (Vellinga, 2004). Agaricaceae includes 3 taxa; agaricoid, secotioid and gasteroid taxa (Moncalvo et al., 2000; Matheny et al., 2006 and Kirk et al., 2008). There is a morphological evidence for a close relationship between agaricoid (Agaricus sp.) and gasteroid taxa (Lycoperdon sp.) (Agerer, 2002).

Podaxis is a desert puffball in agaricoid taxa, have a worldwide distribution and tend to be found growing solitary or scattered on sandy soils, especially in semi-arid regions. Early studies suggest that Podaxis related to the genus Coprinus (Miller \& Miller, 1988). But, its phylogenetic relation with the genera of Agaricus and Leucocoprinus was confirmed using sequences of rDNA genes (Hopple Jr \& Vilgalys, 1999). Hence, it was transferred to the family Agaricaceae from the now obsolete family name Podaxaceae. Podaxis sp. was reported to be growing in free life style or in a symbiotic association with termites at the semideserts of Africa, Asia, Australia and America (Baseia \& Galvão, 2002; Rocabado et al., 2007; Conlon et al., 2016; Abdalla et al., 2016 and Buys et al., 2018). Their fruiting bodies have several medicinal properties for treatment of skin diseases, inflammation and against sunburn (Al-Fatimi et al., 2006). The methanolic extracts of Podaxis exhibited antimicrobial activities against pathogenic bacteria and fungi to human and some plants (Diallo et al., 2002 and Feleke \& Doshi, 2018). Their dark purple spores are used as a hair stain, and a fly repellent (Cleland \& Johnston, 1933). Podaxis has several common names as black powderpuff (Grey \& Grey 2005), desert shaggy mane (Yousaf et al., 2013), Khumbi, Al-Arjoon and Kama (Muhsin et al., 2012 and Mahmound \& Al-Ghamdi, 2014), and as Faswat al-dheib (Kreisel \& Al-Fatimi, 2004).

Leucocoprinus is a gilled mushroom of agaricoid taxa of family Agaricaceae that is common worldwide in the tropics and

\#Corresponding author email: akaelsayed@yahoo.co.uk; Tel: 572403866; Fax: +2057403868; Cell phone: 01285696169 DOI: 10.21608/ejbo.2019.5990.1255

Edited by: Prof. Dr. Salama A. Ouf, Faculty of Science, Cairo University, Giza 12613, Egypt.

C2019 National Information and Documentation Center (NIDOC) 
subtropics (Vellinga, 2004). L. birnbaumii frequently occurs on decayed plant matter in greenhouses and flowerpots with a common name "flowerpot parasol". It benefits greatly from human disturbance as they grow quickly in potting soils and greenhouses (Kumaresan et al., 2011). L. birnbaumii is a pale-spored member of the family Agaricaceae (formerly Lepiotaceae). It was first published as Agaricus luteus (Bolton, 1788) and Lepiota lutea (Arora \& Hershey, 1986). After that, it was found in Prague by a garden inspector named Birnbaum; and named L. birnbaumii (Roberts \& Evans, 2011). Leucocoprinus was accommodated in a confusing position with the sulcate/plicate species intermediate between Leucoagaricus (La.) Locq. ex Singer and Macrolepiota Singer (Singer, 1986). This distinction was clarified with the discovery of pseudoparaphyses between its basidia, which absent in Leucoagaricus species. This yellow lepiota (L. birnbaumii) is inedible, slightly poisonous mushroom causing significant stomach problems (Bartsch et al., 2005). However, there are some studies on its cultivation and fruitbodies production (He et al., 2001). The yellow color of the mushrooms was related to some alkaloids known as birnbaumins (Vellinga, 2009). A series of fatty acids were identified from, L. birnbaumii using HPLCNMR and HPLC-MS and displayed a selective anti-microbial activity (Brkljača \& Urban, 2015). Their natural occurrence is in Southern and Central Africa, South and North America and Europe. It is most common during periods of hot, humid weather.

Different criteria for mushrooms classification have been used, that caused a difficulty of studying mushrooms in a systematic manner (Guzmán-Dávalos et al., 2003). Molecular markers depending on DNA techniques are quicker and more reliable to establish the identification and taxonomy of wild and cultivated mushrooms (Hibbett et al., 1997). Family agaricaceae gain the focus of several molecular-phylogenetic studies, with extensive concentration on common genera; Lepiota (Vellinga, 2004), Coprinus and Podaxis (Keirle et al., 2004). Phylogenetic studies have used random repeated nuclear ribosomal RNA genes (rDNA), e.g. the nuclear large subunit ribosomal RNA gene (nLSU) (Larsson \& Jeppson, 2008) and internal transcribed spacers 1 and 2 flanking the 5.8S region (nrITS) (Vellinga, 2004).
Current study aimed to identify and classify two Egyptian mushrooms of family agaricacea using classical morphological methods compared with a molecular technique for definite identification.

\section{Materials and Methods}

\section{Collection and description of specimens}

Fruitbodies of two different mushrooms were collected during forays for macrofungi from different regions in Egypt. First specimen was collected from Zaranik protected area at North Sinai in March 2010, while the second specimen was collected from El-Sinania orchards (Damietta) in September 2014. The habitat and environment features of collection sites were recorded.

Both specimens were described and identified based on macromorphological characters of fruitbodies as colour, size of cap and stalk according to Smith et al. (1981), Pegler (1986) and Phutela et al. (1998). For microscopic features of the specimen, thin hand sections through hymenium layer were prepared in water and $5 \% \mathrm{KOH}$ solution and then observed under Optika B-350 light microscope with 400x magnification.

The fruitbodies of both mushrooms were dried at room temperature then preserved in the Fungal Herbarium of Botany and Microbiology Department, Faculty of Science at Damietta University.

\section{DNA extraction}

The genomic DNA was extracted from fresh clean fruitbodies using the procedure described by Sandhu et al. (1995). Small samples of fruitbodies were suspended in $200 \mu \mathrm{l}$ of TE buffer (10mM Tris-HCl, pH 8.0, ImM EDTA), and grinded using a sonicator for few seconds. $500 \mu \mathrm{l}$ extraction buffer $(50 \mathrm{mM}$ Tris- $\mathrm{HCl}, \mathrm{pH}$ 7.5; 50mM EDTA, $\mathrm{pH} 8.0 ; 1 \%$ Sodium dodecyl sulphate) were added to an equal volume of sample in a micro tube and then incubated at $65^{\circ} \mathrm{C}$ for $30 \mathrm{~min}$. After incubation, $600 \mu \mathrm{l}$ of a phenol mixture (25 phenol: 24 chloroform: 1 isoamylalcohol) was added, mixed well then centrifuged at $12000 \mathrm{rpm}, 4^{\circ} \mathrm{C}$ for $10 \mathrm{~min}$. Extracted DNA was precipitated by $1 \mathrm{ml}$ of isopropanol, washed with cold ethanol (75\%) and resuspended in water free nuclease then stored at $-20^{\circ} \mathrm{C}$ until used for PCR amplification. 
PCR amplification and sequencing of ITS-5.8S rRNA region

ITS-5.8S rRNA regions were amplified and sequenced using the oligonucleotide primer pair of ITS5/ITS4 (White et al., 1990). The primers sequences ITS5 (5'-GGAAGTAAAAGTCGTAACAAGG-3') and ITS4 (5'-TCCTCCGCTTATTGATATGC-3') were made by BIONEER (South Korea). Amplification reactions were performed in $25 \mu \mathrm{l}$ containing $0.25 \mu \mathrm{M}$ of each primer, $2.5 \mu \mathrm{l}$ (ca. 10 ng) of genomic DNA and one PCR bead (PuReTaq Ready-To-Go; Amersham Biosciences). PCR was performed using the initial denaturation at $94^{\circ} \mathrm{C}$ for $4 \mathrm{~min}$, followed by 35 cycles at $94^{\circ} \mathrm{C}$ for $1 \mathrm{~min}, 55^{\circ} \mathrm{C}$ for $1 \mathrm{~min}$ and $72^{\circ} \mathrm{C}$ for $2 \mathrm{~min}$, then final extension at $72^{\circ} \mathrm{C}$ for $10 \mathrm{~min}$.

\section{Alignment and phylogenetic analyses}

Obtained ITS-rDNA sequences were subjected to a BLAST search against the NCBI database (Altschul et al., 1997). The best DNA sequence similarities with our ITS region were obtained from NCBI GenBank and aligned using Clustal Omega (Sievers et al., 2011). Unalignable regions were excluded and the sequences from the same species and unidentified organisms were discarded. Finally, phylogenetic tree analyses were conducted using MEGA version 4 (Tamura et al., 2007). The neighbour-joining was performed using the maximum composite likelihood methods (Tamura \& Nei, 1993).

\section{$\underline{\text { Results }}$}

\section{Habitat}

The two mushroom specimens were collected from different habitat in North Egypt, during different seasons of the year and different climatic conditions. The fruitbodies of the first specimen were collected from Zaranik protected area at North Sinai (N 31.11467 and 33.41011) in spring (March) of 2010 after rainy winter. It was growing in groups on sandy soil of semiarid desert environment with few grasses. While, the second specimen were collected from a fruit farms at El-Senania, Damietta district in late summer (September) of 2014, at N 31.4412E $31.7791^{\circ}$. They were found growing in a small clump upon dead trunk of Citrus limon tree. Weather conditions were hot to worm, temperature ranges were $\left(31-39^{\circ} \mathrm{C}\right)$ to $(23-$ $24^{\circ} \mathrm{C}$ ) with no precipitation. Their life-cycle was last only after a couple of days and fast-fading quickly.

\section{Morphological characters}

Morphological analysis of the collected fruitbodies for both specimens was carried out at laboratory. The first specimen is a gasterocarp, dry and stipitate, $7.5-18.0 \mathrm{~cm}$ in height, consists of an elongated cap on a rigid, woody stem (Fig. 1 A). The cap is white with shaggy scales and brown patches; peridium was $3.0-8.0 \mathrm{~cm}$ in length and $2.0-3.0 \mathrm{~cm}$ in diameter, sub-conical shaped with rounded apex. Exoperidium is smooth to scaly, generally flaking to reveal the endoperidium which is dark brown at maturity, lacerate dehiscing from the lower edge and eventually exposing gleba which is deep brown. At maturity, it splits and a brown-black spore mass dispersed by the wind. Stipe is straight, $4.5-10 \mathrm{~cm}$ long and up to $1 \mathrm{~cm}$ in diameter; pale to brown and bulbous at the base. Under light microscope; capillitium is yellowish brown to black or deep red when mature, threads up to $10 \mu \mathrm{m}$ in diameter with wall spirally thickened rarely branched or septated. Basidiopores were oval to subglobose, $7.5-12.5 \times 6.5-8.7 \mu \mathrm{m}$ in size and $Q$ value $=1.27$. The surface of the spores is smooth, yellow to reddish brown with double wall, truncate base and apical pore (Fig. 1 B). Hence, this specimen was identified as Podaxis pistillaris.

The second specimen was a gilled mushroom from agaricoid taxa with bright, canary-yellow color but become dingy with age. The lepiota is a classic cap-and-stem mushroom with delicate, tightly packed gills underneath a parasol-shaped cap (Fig. 2 A). When young, the cap was bell shaped, later becoming broadly conic and 3.5$4.0 \mathrm{~cm}$ in diameter; cap surface was squamulose with easily detached scales. The gills were free (not attached to the stem), yellow to pale yellow, crowded, covered by a partial veil when young, which ruptures to leave a fragile, evanescent collar on the stem. Stipe is $4.5-5.0 \mathrm{~cm}$ long, $0.3-$ $0.9 \mathrm{~cm}$ broad, concolorous with a smooth surface. It was equal but enlarged at the base with an annulus, and volva absent. Spore print is white. Microscopically, the species is distinguished by its thick-walled, smooth, colorless ellipsoid spores that are dextrinoid, have a germ pore, and measure about $6-8 \times 5-6 \mu \mathrm{m}, \mathrm{Q}$-value is 1.33 (Fig. 2 B). Basidia are clavate, four spored and pseudopraphysis present. Hence, this specimen 
was identified as Leucocoprinus birnbaumii.

\section{ITS-rDNA identification}

Both mushrooms were identified by Internal Transcribed Sequence (ITS) region using the sequence data deposited in National Centre for Biotechnology Information (NCBI). The obtained nucleotide sequence of the ITS region included 5.8S rRNA gene was $670 \mathrm{bp}$ for the Podaxis isolate (Accession No: HE863812- under name; $P$. pistillaris fallal). While it was $748 \mathrm{bp}$ for the Leuccocoprinus isolate (Accession No: LN827701- under name; L. birnbaumi EGDA). BLAST homology search in NCBI GenBank revealed $97 \%$ identity for $P$. pistillaris fallal and 99\% for L. birnbaumii EGDA with other similar listed species. The phylogenetic tree based on the ITS rDNA sequence (Fig. 3) showed that both isolates are located into cluster species of family Agaricaceae. $P$. pistillaris isolate is clustered in Podaxis clade closely with Macrolepiota clade, than Calvatia, Bovista and Lycoperdon species and away from Coprinus - Lepiota clade. While, L. birnbaumii is clustered in Leucocoprinus clade next to Leucoagaricus clade, close to Lepiota Coprinus clade and away from Chlorophyllum clade.

\section{Discussion}

Agaricaceae(Basidiomycota,Agaricomycotina, Agaricomycetes, Agaricomycetidae, Agaricales) is a well-known family of Agaricales with global distribution. To date, few comprehensive studies have been published on wild mushrooms of Agaricaceae in Egypt and few members of this group were listed (El-Fallal, 2001, 2003; ElFallal \& El-Diasty, 2006; Ahmed, 2014; ElGharabawy, 2016; El-Fallal et al., 2017 and ElFallal, 2013). Although little attention has been paid to the Egyptian gasteroid fungi as Cyathus stercoreus, isolated from New Damietta of Egypt (El-Fallal \& Moussa, 2008). Therefore, in order to expand knowledge of the Egyptian macroflora and Agaricaceae members, this paper presents detailed descriptions, as well as the taxonomy and ecology of two Agaricaceae species from Egypt.

Current study revealed two important macrofungi from two different sections of family Agaricacea. One is a desert gasteriod mushroom " $P$. pistillaris", grow and persist in arid and semi-arid areas around the world, fruiting mainly after rainy seasons. Their spores can live for many years without water under the desert sands, waiting for rain to fruit. Hence, Bedouin Arabs of Sinai call this desert mushroom as "hyena's fart" in Arabic as they pop up suddenly like the hyenas do. Also, they use it as a roasted food in Sinia due to their rich proteins, essential amino acids, carbohydrates, lipids and minerals (Khaliel et al., 1991). It is a rather polymorphic species with great variation in the size of the basidiomata, basidiospores and structure of the capillitium hyphae (De Villiers et al., 1989 and Baseia \& Galvão, 2002). Capillitium of Podaxis was pale yellow brown to black, deep red under microscope, threads up to $10 \mu \mathrm{m}$ in diameter with wall spirally thickened rarely branched or septated as described by Miller \& Miller (1988). The spores were thickwalled, this result agrees with the observations made by Conlon et al. (2016), who reason that free-living, desert dwelling species have thickwalled spores as it may help prevent desiccation in desert-like dry environments. Iraqi isolate of P. pistilaris (Muhsin et al., 2012) were similar in size and morphological characters however the basidiospore were globose to sub globose with larger size 10-14×9-13um. Morevore, $P$. pistilaris was recorded in desert regions of neighbor countries with similar morphology as Saudi Arabia (Abou-Zeid \& Altalhi, 2006) and Sudan (Abdalla et al., 2016). The narrow stipe, bulbous cap and large spores of the specimen were suggested to be adaption for free life style in a nutrient-poor environment of desert. This could maximize reproductive success and minimize the cost of growth, unlike Podaxis spp. that grow symbiotic life style with termites (Conlon et al., 2016). It is used for food in other countries as India and Saudia Arabia (Jiskani, 2001).

The second is a gilled agaricoid mushroom; L. birnbaumii. Their bright yellow coloration and wide distribution with human living made it easily recognized mushroom. Although, there is a confusion regarding the structure of the pileus covering and sometimes only the upper contextual elements are described and illustrated (Pegler, 1972). The macroscopic and microscopic characters of the collected specimen (L. birnbaumii EGDA) are approximately similar to those descried by Baroni \& Watling (1999) and Birkebak (2010). In addition, these morphological features agree with what described in the trial identification 

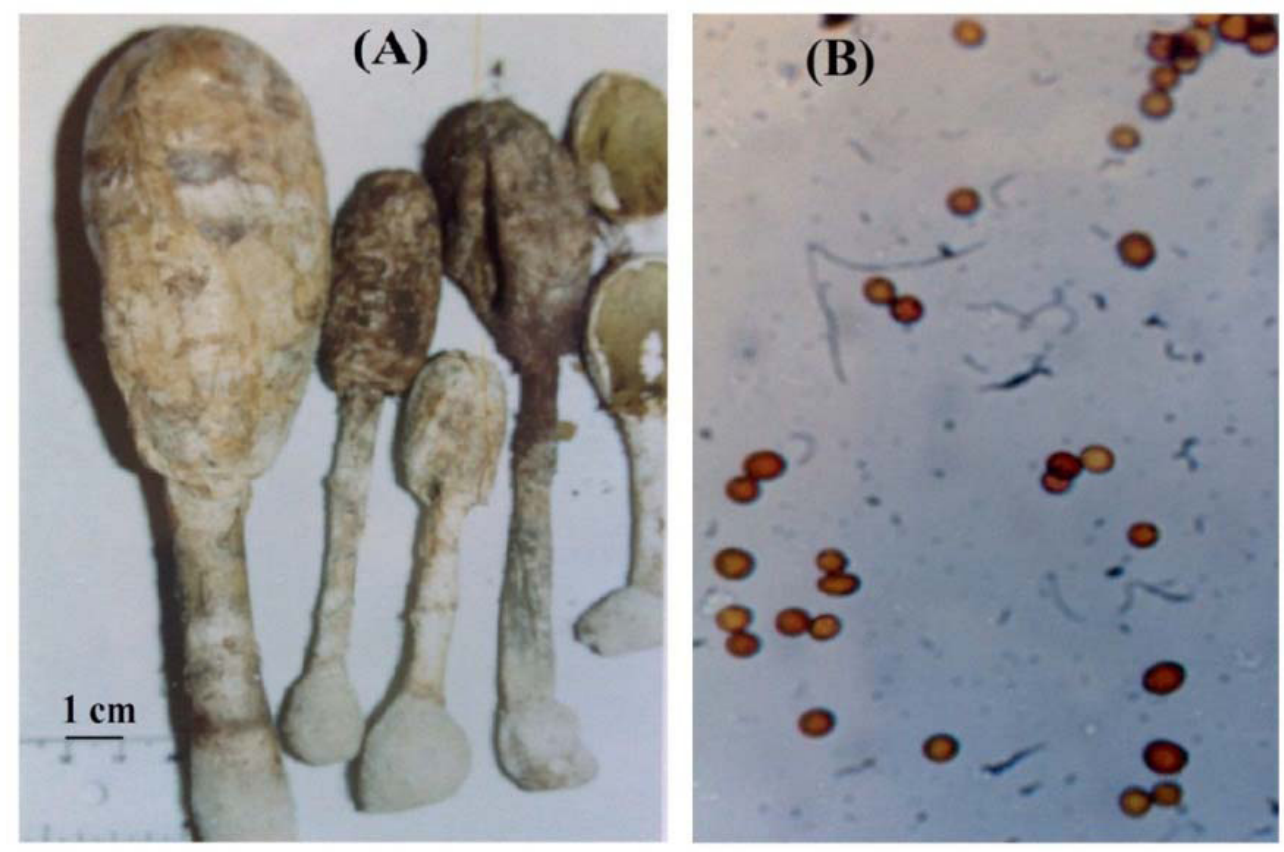

Fig. 1. Morphology of Egyptian Podaxis pistillaris fruiting bodies; (A) Dry gasterocarp with elongate cap and rigid woody stem, (B) Light microscopy field showing reddish brown subglobose basidiospores.
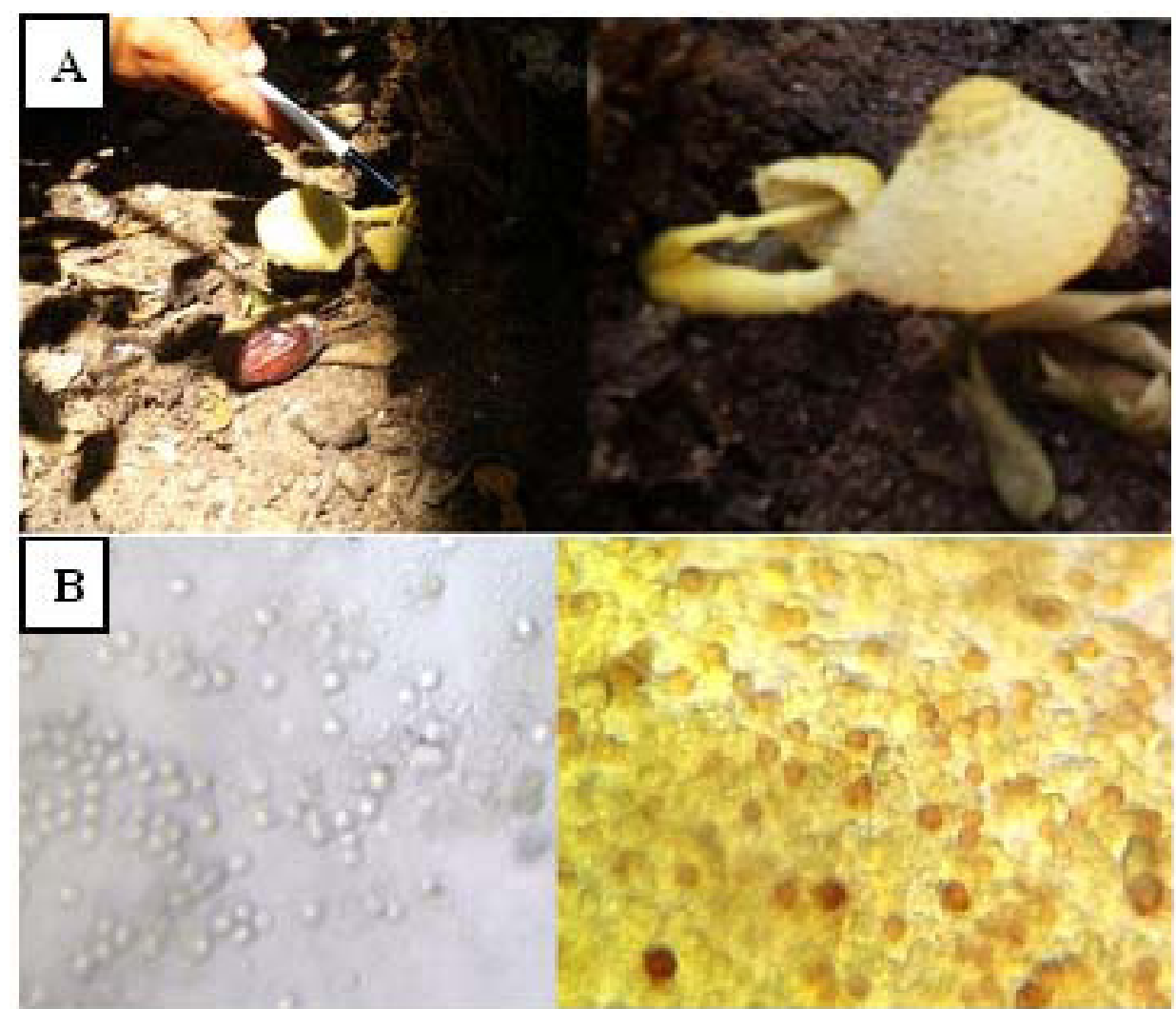

Fig. 2. Morphology of Egyptian Leucocoprinus birnbaumii fruiting bodies; (A) Canary-yellow colored agaricmushroom with a bell-shaped cap and concolorous stipe growing on dead lemon tree trunk, (B) Light microscopy field showing colorless ellipsoid basidiospores on left and brown colored with Melzer reagent on right. 


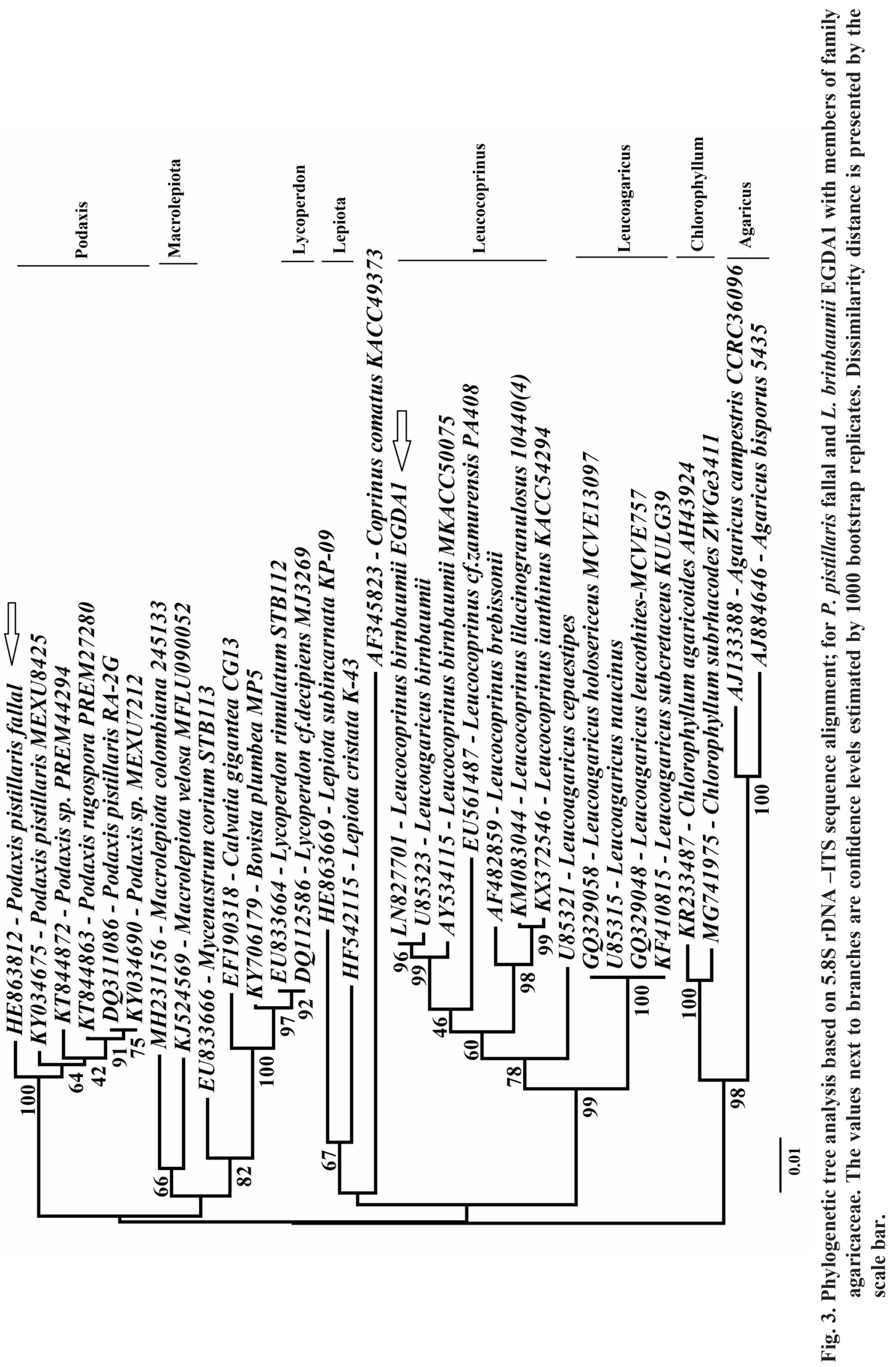


key of Pacific Northwest Lepiota (Sieger, 2003). However, L. birnbaumii described by Pegler (1977) has slightly larger fruit bodies (pileus $1-5 \mathrm{~cm}$ and stipe $4-8 \times 0.2-0.4 \mathrm{~cm})$ and spores $(7-10 \times 4.7-7 \mu \mathrm{m})$ than L. birnbaumii EGDA. Also, the specimen reported by Santhosh (2015) from Karnataka had a pale yellow cap with little larger in size $(5 \mathrm{~cm})$. While, the reported species from different regions of India (Dutta et al., 2011; Kumaresan et al., 2011; Senthilarasu, 2014 and Senthilarasu \& Kumaresan, 2016) had smaller cap (1.5-3.5cm), little longer stipe $(7.0-9.5 \times 0.2-1.1 \mathrm{~cm})$, and larger spores $(\mathrm{Q}$ value $=$ up to 1.58$)$.

This mushroom grows saprobically upon dead and decaying plant debris and favors plant pots, greenhouses habitats, (Dutta et al., 2011 and Senthilarasu \& Kumaresan, 2016). However in current study; it was growing naturally on dead lemon tree in fruit orchards. They require warm weather with some moisture to stay fresh and usually fruit in late spring and summer. Hence, their life-cycle may last only after a couple of days and vanish almost immediately when found in dry weather as our specimen.

Identification of macrofungi to specieslevel based on morphology of fruitbody alone is sometimes problematic and confusing. Thus, phylogenetic evaluation of species using molecular data is a necessity for accurate taxonomy. Alignment ITS sequences with other sequences in Gene bank confirmed the identification of the two mushrooms as P. pistillaris and L. birnbaumi. According to phylogenetic tree based on ITS sequences, both isolates were clustered in the group of family Agaricaceae. P. pistillaris was clustered with Macrolepiota clade and showed significant similarities with members of family Agaricaceae, despite the morphological differences between it and other members of the family as spores and gill characters. On the other hand, it clustered away from genera of Bovista, Calvatia and Lycoperdon which are similar in spore formation. This result agree with the molecular studies of Moncalvo et al. (2002) which failed to indicate a close relationship between Podaxis and Coprinus comatus despite their similarity in overall appearance. Inside the Podaxis clade; ITS of the Egyptian P. pistillaris fallal aligned next to the P. pistillaris (Acc. No: Ky034675) isolate from Mexico with good identity value $(97 \%)$. This Mexican isolate were similar also in morphological characters however its basidiospores had larger size $14 \times 13 \mu \mathrm{m}$ with smaller
$\mathrm{Q}=1.08$ and were growing on similar environment of sandy clay soil with some grass (Medina-Ortiz et al., 2017). Also, the Namibian isolate of Podaxis (Acc. No: KT844872) showed the same identity value $(97 \%)$ with our isolate and has similar size of fruitbody and basidiospore (Conlon et al., 2016).

The Egyptian L. birnbaumii EGDA was clustered in Leucocoprinus clade next to Leucoagaricus clade and close to Lepiota Coprinus clade and away from Chlorophyllum clade. However L. birnbaumii is not a member of the Lepiota genus at all, older name for this mushroom "yellow lepiota" places it in the genus with the Latin epithet Lepiota lutea. Although this lemon-yellow lepiota mushroom is not as closely related to the shaggy parasol mushrooms (Chlorophyllum rhacodes) as it is to mushrooms of the genus Coprinus. Like the coprinoid mushrooms, L. birnbaumii is a decomposing mushroom; grow on dead organic matter (Birkebak, 2010). ITS of L. birnbaumii EGDA aligned next to the American L. birnbaumii isolate (Acc. No: U85323) collected by Johnson \& Vilgalys (1999) from North Carolina with significant similarity value (99\%).

\section{Conclusion}

This is the first description of two basidiomycetes from family Agaricacea in Egypt; Podaxis pistillaris fallal and Leucocoprinus birnbaumii EGDA. The first was collected from sandy soil in Zaranik desert at North Sinai, while the second was collected from a dead lemon tree in El-Sinania orchards at Damietta. Both species were identified based on classical morphology and phylogenetic analysis of ITS sequences. This study will encourage future phylogenetic diversity analyses on this widely distributed yet taxonomically poorly studied genera of Agaricomycetes. Moreover, it provides new additions to the macroflora of Egypt.

Acknowledgement: Many thanks to Prof. Dr. Abd El-Hamid Khder (Botany and Microbiology Dept., Faculty of Science, Damietta University) who kindly collected the Podaxis fruitbodies.

\section{References}

Abdalla, R., Ahmed, A., Abdalla, A., Abdelmaboud, O., Khiery, N., Elriah, N. and Saeed, M. (2016) Some wild edible and medicinal mushroom species at Khartoum and Sinnar States-Sudan. Journal of Microbial \& Biochemical Technology, 8, 503-506. 
Abou-Zeid, A. and Altalhi, A. (2006) Survey of some mushrooms in Al-Taif governorate of Saudi Arabia. World Journal of Agricultural Sciences, 2(1), 01-05.

Agerer, R. (2002) Rhizomorph structures confirm the relationship between Lycoperdales and Agaricaceae (Hymenomycetes, Basidiomycota). Nova Hedwigia, 75, 367-385.

Ahmed, E.M.S. (2014) Molecular and physiological studies on growth and fruiting of some wild and cultivated Agaricus species. MSc. Thesis, Damietta University, Egypt.

Al-Fatimi, M., Jülich, W.D., Jansen, R. and Lindequist, U. (2006) Bioactive components of the traditionally used mushroom Podaxis pistillaris. Evidence-Based Complementary and Alternative Medicine, 3, 87-92.

Altschul, S.F., Madden, T.L., Schäffer, A.A., Zhang, J., Zhang, Z., Miller. W. and Lipman, D.J. (1997) Gapped BLAST and PSI-BLAST: A new generation of protein database search programs. Nucleic acids Research, 25, 3389-3402.

Arora, D. and Hershey, H. (1986) "Mushrooms Demystified", Berkeley, USA, Ten Speed Press.

Baroni, T.J. and Watling, R. (1999) Taxonomic and mycogeographic notes on some Malaysian fungi. IV. Notes on Clitopilus and Rhodocybe. Mycotaxon, 72, $57-72$

Bartsch, A., Bross, M., Spiteller, P., Spiteller, M. and Steglich, W. (2005) Birnbaumin A and B: Two unusual 1-hydroxyindole pigments from the "Flower Pot Parasol" Leucocoprinus birnbaumii. Angewandte Chemie International Edition, 44, 2957-2959.

Baseia, I.G. and Galvão, T.C. (2002) Some interesting Gasteromycetes (Basidiomycota) in dry areas from Northeastern Brazil. Acta Botanica Brasilica, 16, 01-08.

Birkebak, J.M. (2010) The genus Leucocoprinus in western Washington. Mycotaxon, 112, 83-102.

Bolton, J. (1788) "An History of Fungusses, Growing about Halifax", author and sold in Halifax.

Brkljača, R. and Urban, S. (2015) Rapid dereplication and identification of the bioactive constituents from the fungus, Leucocoprinus birnbaumii. Natural Product Communications, 10, 95-98.
Buys, M., Conlon, B., Licht, H.D.F., Aanen, D., Poulsen, M. and De Beer, Z. (2018) Searching for Podaxis on the trails of early explorers in southern Africa. South African Journal of Botany, 115, 317.

Cleland, S.J.B. and Johnston, T.H. (1933) "The Ecology of the Aborigines of Central Australia".

Conlon, B.H., De Beer, Z.W., Henrik, H., Aanen, D.K. and Poulsen, M. (2016) Phylogenetic analyses of Podaxis specimens from Southern Africa reveal hidden diversity and new insights into associations with termites. Fungal Biology, 120, 1065-1076.

De Villiers, J., Eicker, A. and Van Der Westhuizen, G. (1989) A new section and two new species of Podaxis (Gasteromycetes) from South Africa. South African Journal of Botany, 55, 159-164.

Diallo, D., Sogn, C., Samaké, F.B., Paulsen, B.S., Michaelsen, T.E. and Keita, A. (2002) Wound healing plants in Mali, the Bamako region. An ethnobotanical survey and complement fixation of water extracts from selected plants. Pharmaceutical Biology, 40, 117-128.

Dutta, A., Pradhan, P., Giri, S., Roy, A. and Acharya, K. (2011) Leucocoprinus birnbaumii (Corda) Singer. An addition to macrofungal flora of West Bengal, India. Journal of Mycology and Plant Pathology, 41, 316.

El-Fallal, A.A. (2001) Decolourization of the dye Poly R-478 and oxidation of some phenols by some Basidiomycetes. Bulletin of Faculty of Science, Assiut University, 30, 271-283.

El-Fallal, A.A. (2003) Agaricales from the countryside and grasslands of East Delta region, Egypt. Journal of Environmental Sciences, University of Mansoura, Egypt, 26, 339-352.

El-Fallal, A.A. (2013) Diversity of Macrofungi in North Nile Delta. Third International Congress of Fungal Conservation, 11-15 November, 2013. Akayaka, Mugla, Turkey.

El-Fallal, A.A. and El-Diasty, G.G. (2006) Evaluation of Egyptian white-rot fungi for their ability to produce ligninolytic enzymes and decolorization of Poly R. Bulletin of Faculty of Science, El-Minia University, 17, 1-44.

El-Fallal, A.A. and Moussa, Z. (2008) Prospects for 
biocontrol of brown rot disease of potato in vitro and under greenhouse conditions. Plant Pathology Journal, 7, 54-64.

El-Fallal, A.A., El-Sayed, A.K.A. and El-Gharabawy, H.M. (2017) First Record of Lepista sordida (Schumach) Singer in Eastern North Africa. Egyptian Journal of Botany, 57, 111-118.

El-Gharabawy, H.M. (2016) Wood decay of trees by basidiomycete fungi in the North East Delta region. Ph.D. Thesis, Damietta University, Egypt.

Feleke, H.T. and Doshi, A. (2018) Antimicrobial activity and bioactive compounds of Indian wild Mushrooms. Indian Journal of Natural Products and Resources (IJNPR)[Formerly Natural Product Radiance (NPR)], 8, 254-262.

Grey, P.M. and Grey, E.J. (2005) Fungi Down Under: The Fungimap Guide to Australian Fungi/Pat Grey \& Ed Grey, Fungimap.

Guzmán-Dávalos, L., Mueller, G.M., Cifuentes, J., Miller, A.N. and Santerre, A. (2003) Traditional infrageneric classification of Gymnopilus is not supported by ribosomal DNA sequence data. Mycologia, 95, 1204-1214.

He, X., Kang, X. and Li, C. (2001) Studies on cultivation of mycelium and fruit-body of Leucocoprinus birnbaumii. Wei sheng wu xue tong bao, 28, 27-32.

Hibbett, D.S., Pine, E.M., Langer, E., Langer, G. and Donoghue, M.J. (1997) Evolution of gilled mushrooms and puffballs inferred from ribosomal DNA sequences. Proceedings of the National Academy of Sciences, 94, 12002-12006.

Hopple, Jr J.S. and Vilgalys, R. (1999) Phylogenetic relationships in the mushroom genus Coprinus and dark-spored allies based on sequence data from the nuclear gene coding for the large ribosomal subunit RNA: Divergent domains, outgroups and monophyly. Molecular Phylogenetics and Evolution, 13, 1-19.

Jiskani, M. (2001) Growing mushrooms (step ahead to boost up the economy of Pakistan). Pakistan Journal of Economic and Management, July-Sept., 2001, 1517.

Johnson,J. and Vilgalys, R. (1999) Phylogenetic relationships within Lepiota sensu lato inferred from nuclear and mitochondrial rDNA sequences. Mycologia, 91, 443-458.

Keirle, M., Hemmes, D. and Desjardin, D. (2004) Agaricales of the Hawaiian Islands. 8. Agaricaceae: Coprinus and Podaxis; Psathyrellaceae: Coprinopsis, Coprinellus and Parasola. Fungal Diversity, 15.

Khaliel, A., Abou-Heilah, A. and Kassim, M. (1991) The main constituents and nutritive value of Podaxis pistillaris. Acta Bot Hung, 36, 173-9.

Kirk, P.M.C., Cannon, P.F., David, J.C. and Stalpers, J.A. (2008) "Ainsworth and Bisby's Dictionary of the Fungi", $10^{\text {th }}$ ed. Wallingford, UK, CABI Publishing.

Kreisel, H. and Al-Fatimi, M. (2004) Basidiomycetes and larger Ascomycetes from Yemen. Feddes Repertorium: Zeitschrift für botanische Taxonomie und Geobotanik 115, 547-561.

Kumaresan, V., Veeramohan, R. and Ganesan, T. (2011) Diversity of white-spored agarics in Puducherry. $J$. Mycol. Plant Pathol. 41, 518-523.

Larsson, E. and Jeppson, M. (2008) Phylogenetic relationships among species and genera of Lycoperdaceae based on ITS and LSU sequence data from north European taxa. Mycological Research, 112, 4-22.

Mahmound, Y. and Al-Ghamdi, A.Y. (2014) Podaxis pistillaris (L. ex Pers.) Fr. recorded from Al Mekwah City, Albaha, Saudi Arabia. Research Journal of Microbiology, 9, 111-114.

Matheny, P.B., Curtis, J.M., Hofstetter, V., Aime, M.C., Moncalvo, J.M., Ge, Z.W., Yang, Z.L., Slot, J.C., Ammirati, J.F. and Baroni, T.J. (2006) Major clades of Agaricales: A multilocus phylogenetic overview. Mycologia, 98, 982-995.

Medina-Ortiz, A.J., Herrera, T., Vásquez-Dávila, M.A., Raja, H.A. and Figueroa, M. (2017) The genus Podaxis in arid regions of Mexico: Preliminary ITS phylogeny and ethnomycological use. Myco Keys, 20, 17.

Miller, O.K. and Miller, H. (1988) "Gasteromycetes: Morphological and Developmental Features, with Keys to the Orders, Families and Genera", Eureka, CA: Mad River Press.

Moncalvo, J.M., Lutzoni, F.M., Rehner, S.A., Johnson, J. 
and Vilgalys, R. (2000) Phylogenetic relationships of agaric fungi based on nuclear large subunit ribosomal DNA sequences. Systematic Biology, 49, 278-305.

Moncalvo, J.M., Vilgalys, R., Redhead, S.A., Johnson, J.E., James, T.Y., Aime, M.C., Hofstetter, V., Verduin, S.J., Larsson, E. and Baroni, T.J. (2002) One hundred and seventeen clades of euagarics. Molecular Phylogenetics and Evolution, 23, 357400.

Muhsin, T.M., Abass, A.F. and Al-Habeeb, E.K. (2012) Podaxis pistillaris (Gasteromycetes) from the desert of southern Iraq, an addition to the known mycota of Iraq. Journal of Basrah Researches (Sciences), 38, 29-35.

Pegler, D.N. (1972) A revision of the genus Lepiota from Ceylon. Kew Bulletin, 27(1), 155-202.

Pegler, D.N. (1977) "A Preliminary Agaric Flora of East Africa", Her Majesty's Stationery Office.

Pegler, D.N. (1986) Agaric flora of Sri Lanka. Kew Bull. Addit Ser. 12, 1-519.

Phutela, R., Kaur, H. and Sodhi, H. (1998) Physiology of an edible gasteromycete, Podaxis pistillaris (Lin. ex. Pers) Fr. Journal of Mycology and Plant Pathology (India), 28(1), 31-37.

Roberts, P. and Evans, S. (2011) "The Book of Fungi". Chicago, USA: University of Chicago Press.

Rocabado, D., Wright, J.E., Maillard, O. and Muchenik, N.F. (2007) Catálogo de los gasteromycetes (Fungi: Basidiomycotina) de Bolivia. Kempffiana, 3, 3-13.

Sandhu, G.S., Kline, B.C., Stockman, L. and Roberts, G.D. (1995) Molecular probes for diagnosis of fungal infections. Journal of Clinical Microbiology, 33, 2913-2919.

Santhosh, D. (2015) Ethnobotanical Survey and Molecular Characterization of Wild Mushrooms from the Parts of Western Ghats Region of Karnataka. University Of Agricultural Sciences Gkvk, Bengaluru.

Senthilarasu, G. (2014) Diversity of agarics (gilled mushrooms) of Maharashtra, India. Current Research in Environmental \& Applied Mycology, 4, 58-78.

Senthilarasu, G. and Kumaresan, V. (2016) Diversity of agaric mycota of Western Ghats of Karnataka, India. Current Research in Environmental \& Applied Mycology, 6, 75-101.

Sieger, R. (2003) Trial key to Pacific Northwest Lepiota and allies. Pacific Northwest Key Council [www. svims. ca/council/Lepiot. doc, accessed 30 November 2006].

Sievers, F., Wilm, A., Dineen, D., Gibson, T.J., Karplus, K., Li, W., Lopez, R., Mcwilliam, H., Remmert, M. and Söding, J. (2011) Fast, scalable generation of high-quality protein multiple sequence alignments using Clustal Omega. Molecular Systems Biology, 7, 539 .

Singer, R. (1986) "The Agaricales in Modern Taxonomy", Koenigstein, Germany, Koletz Scientific Books.

Smith, A., Smith, F. and Weber, N. (1981) "How to Know the Non-gilled Mushrooms|", Wm. C. Brown, Dubuque, IA.

Tamura, K. and Nei, M. (1993) Estimation of the number of nucleotide substitutions in the control region of mitochondrial DNA in humans and chimpanzees. Molecular Biology and Evolution, 10, 512-526.

Tamura, K., Dudley, J., Nei, M. and Kumar, S. (2007) MEGA4: Molecular evolutionary genetics analysis (MEGA) software version 4.0. Molecular Biology and Evolution, 24, 1596-1599.

Vellinga, E.C. (2004) Ecology and distribution of Lepiotaceous fungi (Agaricaceae)-A review-. Nova Hedwigia, 78, 273-299.

Vellinga, E.C. (2009) Nomenclatural Overview of Lepiotaceous Fungi (Agaricaceae) Version 4.8.

White, T.J., Bruns, T., Lee, S. and Taylor, J. (1990) Amplification and direct sequencing of fungal ribosomal RNA genes for phylogenetics. PCR Protocols: A guide to Methods and Applications 18, 315-322.

Yousaf, N., Khalid, A.N. and Niazi, A.R. (2013) Taxonomy of gasteroid fungi from some arid regions of Punjab, Pakistan. Journal of Biodiversity and Environmental Sciences, 3, 253-263.

(Received 29 /11 / 2018 accepted 13 / 2 / 2019) 
Leucocoprinus birnbaumii (Corda) Singerو Podaxis pistillaris (L.) Fr. إضافة جديدة للفطريات المصرية كبيره الحجم

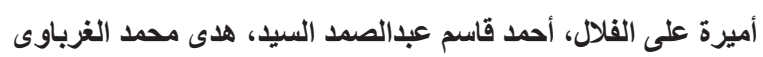

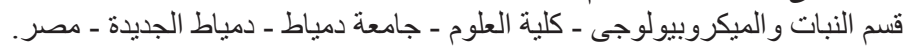

Agaricaceae

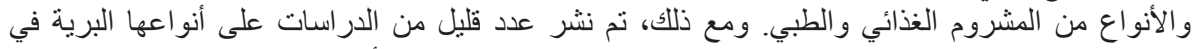

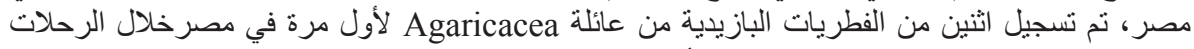

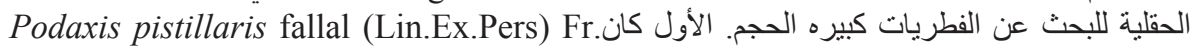

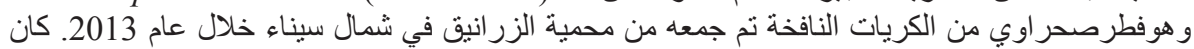

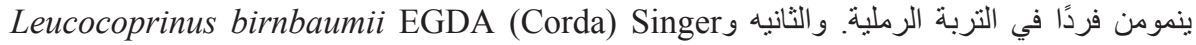

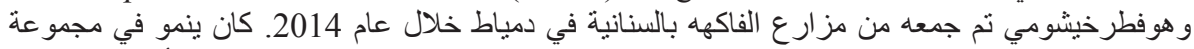

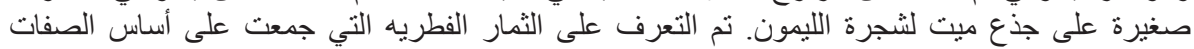

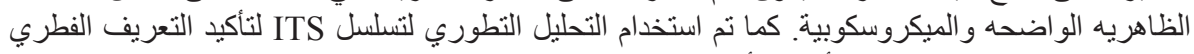

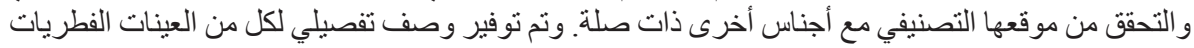

و الصفات البيئية المحيطة. 